\title{
アイソタクチック・ポリプロピレンの 結晶構造について
}

\section{1. まえがき}

アイソタクチック・ポリプロピレンの単斜晶変態の $\mathrm{X}$ 線棈造解晰は, Natta, Corradini が 1960 年 Nuov Cimento 誌汇報告するに及んで，一広絬末となった1。 しかし Natta の発表された雑誌が特殊なものなので, アイソタクチック・ポリプロピレンの結晶構造が十分に 知られていないようである。そこで，これを簡単に紹介 してみたい(以下，アイソタクチック・ポリプロピレン をI. PP.と略すこととする)。

\section{2. 初期に考えられた結晶形}

Natta が最初 I. PP. をつくったときのX線回折図は 第 1 図のようなるのであった。現在快闵中第 4 ピークは さらに2本に分れていることがわかっているが，当時の I. PP. では，この2本が分離できなかったよらである。 繊維周期 $\mathrm{I}=6.50 \AA ̊$ はすぐ決定された。そこで X線回 折の解析の常法どおり，第 1 ピーク 100 , 第 2 ピーク 010 , 第 3 ピーク 110 之指数配当して文ると, 第 4 ピー クは 011 となり,もっともらしい結晶形が計算された。 Nattaの最初に発表した絬晶形

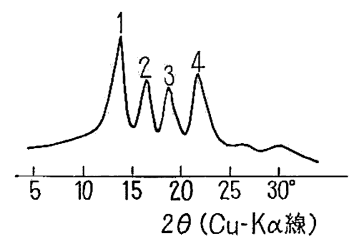

(1) 無配向試料のガイ
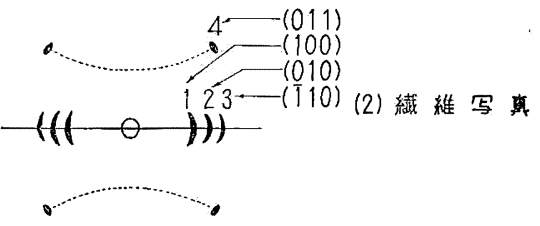

第 1 图 I. PP.のX線回折一初期の帣え方一

* Hiroshi AwAYA 徳山曹達株式会研究部主任研筑員 Structure of Isotactic Polypropylene

Vol. 14, No. 158
粟屋裕*

$$
\left.\begin{array}{l}
\text { a: } 6.56 \AA, \text { b: } 5.45 \AA, c: 6.50 \AA, \\
r: 106^{\circ} 30^{\prime} \text {, 単斜晶 }
\end{array}\right\}
$$

が，これである2゙。

この面指数の考方方が大分長い間行なわれたので，少 し古い本をみると，この指数を用いている。すで過去 のものなので注意を要する。

\section{3. 単斜晶変態の正しい結晶形}

その後，(1) で与光た Natta の結晶形では説明でき ないいくつかの現象がわかってきた。その一つは第 4 ピ 一クの分離である。第 2 図に示すよらに，ただ 1 本と思 われたピークが実は 2 本からなることが明らかになって きた。

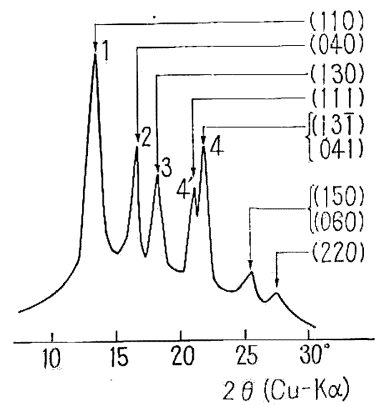

第 2 図 I. PP. のX線回折 (然配向試料)

Natta が改めて再提案した結晶形は次のようなもので ある。

$$
\begin{aligned}
& \text { a: } \quad 6.65 \pm 0.05 \AA \\
& \text { b: } 20.96 \pm 0.15 \AA \\
& \text { c: } \quad 6.50 \pm 0.05 \AA \\
& \beta: \quad 99^{\circ} 20^{\prime} \\
& \text { 単斜品 }
\end{aligned}
$$

これによってX線回折ピークの指数配当をすると，第 1 㤗のごとくである。

その結果, ただらに $h+k=$ 偶数の関係が得られる。 単斜晶でこの関係をもつものは, 空間橎 $\mathrm{C}_{2}{ }_{2}-\mathrm{C}_{2}, \mathrm{C}^{3}$ $\mathrm{C}_{m}, \mathrm{C}_{2 h}^{3}-\mathrm{C}_{2 / m}, \mathrm{C}_{2 h}^{3}-\mathrm{C}_{2 / c}, \mathrm{C}^{4}-\mathrm{C}_{c}$ の 5 種である。そ 
第 1 表 I. PP. の面間隔と指数配当

\begin{tabular}{c|c|c|l|c}
\hline \hline $2 \theta^{*}$ & $\begin{array}{c}\mathrm{d} \\
(\AA)\end{array}$ & 強度 & 指 $h, k, l$ & $\begin{array}{c}\text { 古典的指数 } \\
h, l, l, l\end{array}$ \\
\hline $14.2^{\circ}$ & 6.25 & vs & 110 & 100 \\
$16.9^{\circ}$ & 5.25 & vs & 040 & 010 \\
$18.7^{\circ}$ & 4.75 & vs & 130 & $\overline{1110}$ \\
$21.2^{\circ}$ & 4.20 & $\mathrm{~s}$ & 111 & - \\
$21.9^{\circ}$ & 4.05 & $\mathrm{vs}$ & $13 \overline{1} \sim 041$. & 011 \\
$24.6^{\circ}$ & 3.62 & $\mathrm{mw}$ & 131 & \\
$25.6^{\circ}$ & 3.48 & $\mathrm{~m}$ & $150 \sim 060$. & \\
$27.2^{\circ}$ & 3.28 & $\mathrm{w}$ & 200 & \\
$28.5^{\circ}$ & 3.13 & $\mathrm{~m}$ & 220 & \\
$29.3^{\circ}$ & 3.05 & $\mathrm{mw}$ & $11 \overline{2}$ & \\
$32.9^{\circ}$ & 2.72 & $\mathrm{vw}$ & 170 & \\
$33.6^{\circ}$ & 2.66 & $\mathrm{vw}$ & $24 \overline{1} \sim 221$ & \\
$35.3^{\circ}$ & 2.54 & $\mathrm{vw}$ & $17 \overline{1}$ & \\
$37.6^{\circ}$ & 2.39 & $\mathrm{vw}$ & 260 & \\
$41.2^{\circ}$ & 2.19 & $\mathrm{vw}$ & $190 \sim 310$ & \\
\hline
\end{tabular}

* $\mathrm{Cu}-\mathrm{K} \alpha$ 線による回折角

して，さらに $l=1,2$ のピークを調べると，hol のピー クは $l$ =奇数のときには現われないことがわかる。こう 乙て対称性加ら考光られる空間群は $\mathrm{C}_{\mathrm{s}}^{4}-\mathrm{C}_{c}, \mathrm{C}_{2 h}^{6}-\mathrm{C}_{2 / \mathrm{o}}$ (以下単に $\mathrm{C}_{c}, \mathrm{C}_{2 / a}$ とする) の二つにせばめられる。

\section{3-1. 本結晶形の正しい理由}

\section{3-1-1. 球昆の $X$ 線回折}

Natta の再提出した結㫛形はもっとも確からしい。し かし, これは瀻維構造 (c 軸配向試料) のX線回折で, 一方向からの投影にすぎないからこれだけで完全な知 見が得られたとはい充ない。

Keith らは I. PP. の球晶の研究中, その 1 個の球晶 のマイクロX線回折写真をとることに成功した ${ }^{3)}$ 。これ は籍 3 図のごとき特殊な形であり，c軸方向に垂直な方 向にX線を入れた纎維図形と異なり，201 配向とでもい ら形態を示した。そして，他の結晶满造ではこのパター ンを説明できないことは，Natta の結晶形の正当さを衰 書きするものである。

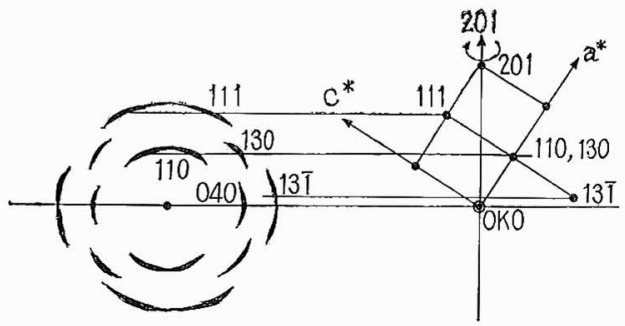

第 3 図 I. PP. 球晶のX線回折パターンとその 説明 (by Keith et al) ${ }^{3)}$

\section{3-1-2. a 軸配向}

著者は I. PP. を無配向状態から莛伸していく過程に

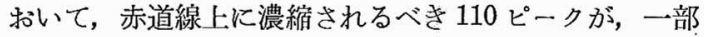
子午線上に取り残される中間段階のあることを発見し だ)。

写真 1 亿不完全延伸と完全延伸の場合のX線回折の比 校を示した5)。I. PP、は延伸方向と c 軸が一致する (2) ものであるが，延伸初期には一部の絬㫛の $\mathrm{a}$ 軸が延伸方 向に並んだため $(1)$ の異常現象を生じる。この関係を第 4 図に示した。

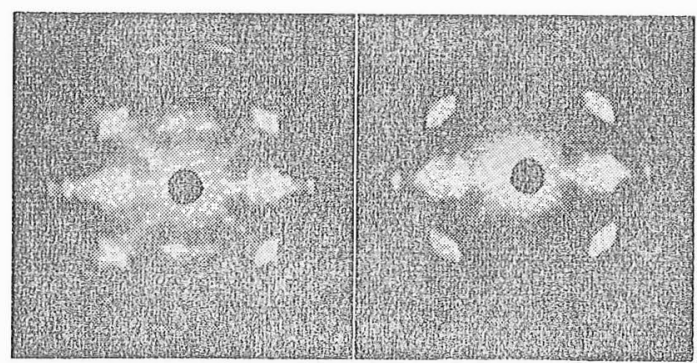

(1) 延伸初期

写真 1. 延伸 I. PP. のX 線回折 ${ }^{5}$

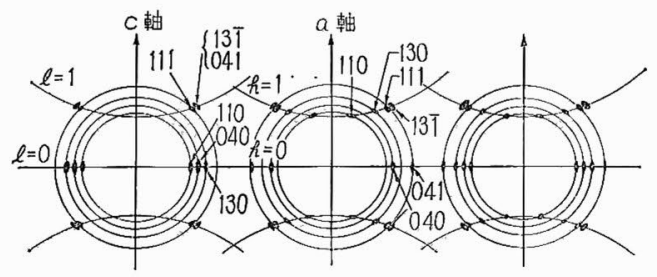

（1） c 朝配向 (2) a 軕配向 (3) 合成 第 4 図 110 異常の説明

\section{3-1-3. 電子線回折}

I. PP.の単結晶を得ることはきわめて困難である。 小林は I. PP. を溶液から析出させた樹枝状晶の一部を 電子顕微鏡および電子線回折によって調べたところ，単 結晶的構造であることを発見した5)。

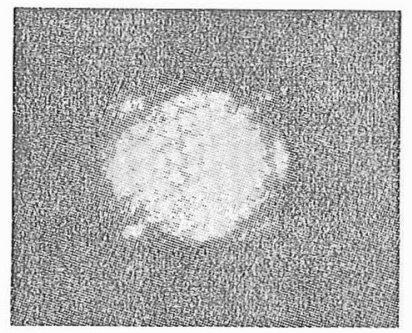

写真 2. I. PP. 樹枝状晶の電子線回折5

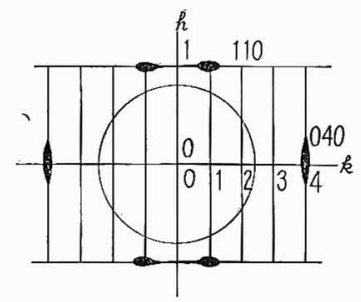

第 5 図 I. PP. 樹枝状晶の電子線回折 
この結果は写真 2 ，第 5 図に示すようなa 軸配向のX 線回折が得られた。

このように種々の方向からとった回折図形のいずれも が，Natta 構造を支持する。

\section{I. PP. の骨格}

プロピレンが重合するさい，二重結合がとけて，二つ の結合法を生じる。第 6 図のI型のみ（あるいは型の み）配列すると，アイソタクチック，I－II交互配列が シンジオタクチック，I， I㔯不規則配列するとアタク チックになる。

さて， I. PP. の織維周期は $6.5 \AA$ Åである。ポリエチ レンのごとき C-C-C のジグザグ状分子の絨維周期は 約 $2.5 \AA$ で,

$$
2.5 \times 2<6.5<2.5 \times 3
$$

I. PP.の繊維周期は C $-\mathrm{C}-\mathrm{C}$ 距離の整数倍にならな い。これは I. PP.の骨格がラセン構造なことを示す。 実際 3 回ラセンである。

そこでI. PP. 主鎖のみを㘼ると，第7図のように， トランス $(\mathrm{T})$ ，ゴーシュ(G)が T-G-T-G とくり返す ことによって，3回ラセンが形成されることがわかる。

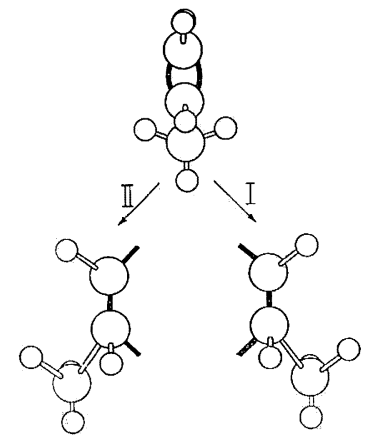

$$
\begin{aligned}
& \left.\begin{array}{l}
\text {-I I- I-I - I- } \\
\text {-II-II-II-II- }
\end{array}\right\} \text { アイソタクチック } \\
& \text { ー I-II-I-II- シンジタタチック } \\
& \text { ーI-II-II-I-II アタクチック }
\end{aligned}
$$

第 6 図 プロピレンモノマー 2 重結合の開き方”

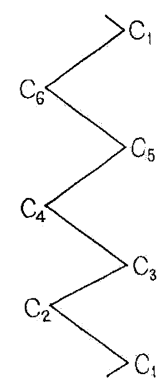

I.PP.の骨格

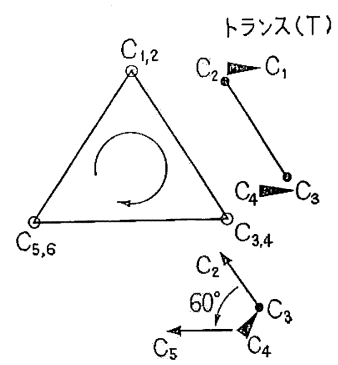

ゴーシュ (G)
右巻あるいは左巻に T-G-T-G と結合 3 回ラセンをつくる。

第 7 図 I. PP. 主鎖の回転

Vos. 14, No. 158
ところで，アイソタクチックには，第6図に示したよ うに I-I-I 型, II-II-II型の 2 種があることを述べ た。これは，骨格のみを一つの平面内にジグザグ型に並 べたとき，侧鎖が全部平面より上侧に出ている場合と， 全部が下側に出ている場合の 2 と拈りることを示す (第 8 図)。

側鎖が紙面より上飞出ている場合を, 右回わり飞回転 させると，側鎖上向の右巻ラセンの I. PP. 骨格ができ 上る。左まわりに回転させると，側鎖下向左巻骨格を生 じる。同様に側鎖が紙面より下に出ている場合には, 右 まわりで側鎖下向の右巻骨格, 左まわりで側鎖上向の左 巻骨格と，4 種類の I. PP. 格骨が生じる (第 9 図) $)^{6) * 1 。}$

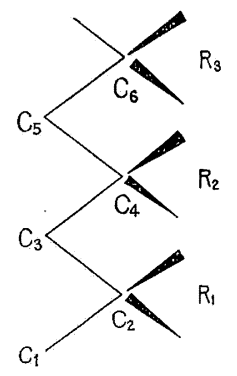

骨格を平面に並へると唄領の $\mathrm{CH}_{3}$ 基は第 6 図の I-I-I の場合すべて紙面より下僛に II-II-II の場合は上側に 向く。I. PP. はこの二つ場合のみ考えればよい。

第 8 図 I. PP. 側鎖のつき方

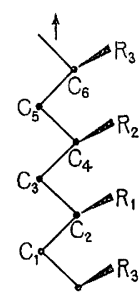

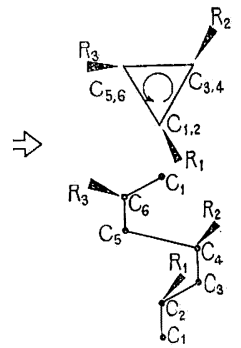

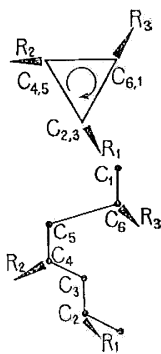

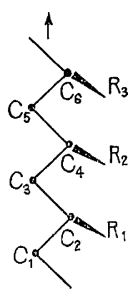

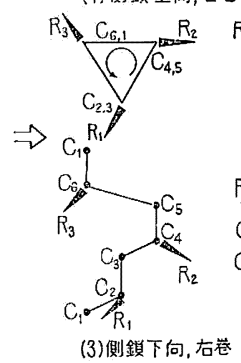

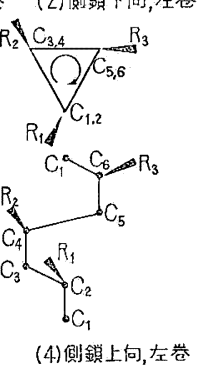

第 9 図 I. PP. 鎖の巻き方

\section{I. PP. の空間配置}

5-1. 一つの鎖について

I. PP.の一つの鎖について考えると，C-C の単結合

*1 田所の図は鎖の方向下を正にとっているが，ここ では上を正の方向にとった。 
距離 $1.54 \AA$ ，骨格の $\mathrm{C}-\mathrm{C}-\mathrm{C}$ 結合角は $114^{\circ}$ である。 側鎖 $\mathrm{CH}_{3}$ 亿関しては $\mathrm{CH}_{3}-\mathrm{C}-\mathrm{C}$ 結合角 $110^{\circ}$ である。

\section{5-2. 空間群}

先に述べたように I. PP. 単斜晶の空間群は $\mathrm{C}_{\boldsymbol{c}}$ か $\mathrm{C}_{2} / \boldsymbol{c}$ 究間群である。

unit cell 中にいくつプロピレンモノマーが入るか考 えねばならない。これはX線回折の結果から

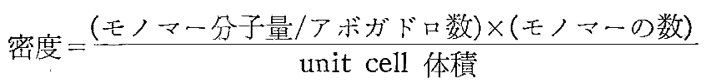

結晶性良好な I. PP.の密度は $0.92 \mathrm{~g} / \mathrm{cm}^{3}$ である。 unit cell の体積は $a \cdot b \cdot c \cdot \sin \beta$ の関係に（2）式を入 れれば良い。こうしてモノマーの数 11.8 を得る。この 数の半端なのは $100 \%$ I. PP. でない子のの密度を用い たためである。艺こで 100\% I. PP. については unit cell 中に 12 個のプロピレソモノマーが入っていること がわかる。1本の I. PP. 鎖は unit cell 中に 3 ケの $\mathrm{C}_{3}$ $\mathrm{H}_{6}$ を含をから，一つの unit cell 中に I. PP. 鎖が 4 個 入っていることになる。

\section{5-2-1. $\mathrm{C}_{\boldsymbol{c}}$ 空間群}

$\mathrm{C}_{0}$ 空間群を第10図に示す ${ }^{7)} \mathrm{C}_{c}$ 空間群は位置の数が四 つなので，第 10 図の○の位置に一つずつ I. PP. 鎖を 配置すればよい。
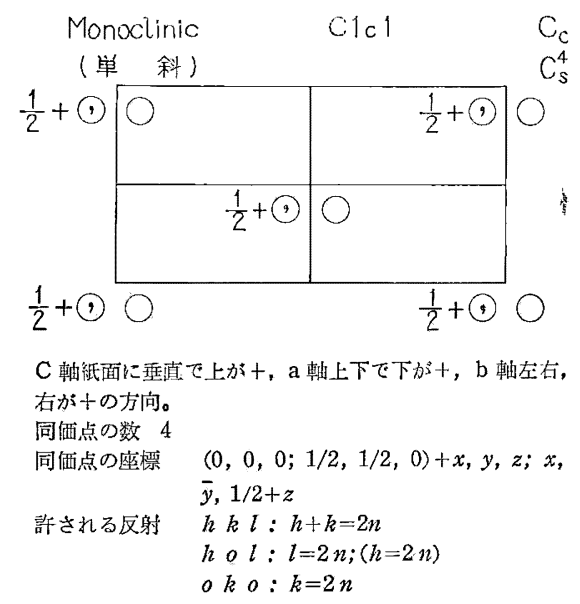

第 10 図 $C_{c}$ 空間群!

今，側鎖が下向きで右巻ラセンの I. PP. 鎖を例にと ると，一つの I. PP. 鎖の原子座標は第 2 表のごとくで ある。

第 2 表の $x, y, z$ を第 10 図の関係汅入れると, unit cell 中の I. PP。鎖の座標が完全に求恋る。第 2 表から $x, \bar{y}, \frac{1}{2}+z$ を求めると，側鎖下向き左巻ラセンのI. PP. 鎖になる。

I. PP. 単斜晶学 $\mathrm{C}_{\boldsymbol{c}}$ 空間群として (001) 面上への投影 を画くと，第 11 図のごとくである。第 11 図は紙面が c
第 2 表 unit cell 中の原子の座標1)

\begin{tabular}{|c|c|c|c|}
\hline & $x$ & $y$ & $z$ \\
\hline $\mathrm{C}_{1}$ & $-0.291(0.709)$ & 0.075 & 0.035 \\
\hline $\mathrm{C}_{2}$ & $-0.076(0.924)$ & 0.100 & 0.151 \\
\hline $\mathrm{C}_{3}$ & $-0.076(0.924)$ & 0.100 & 0.388 \\
\hline $\mathrm{C}_{4}$ & 0.290 & 0.075 & 0.465 \\
\hline $\mathrm{C}_{5}$ & 0.121 & 0.119 & 0.519 \\
\hline $\mathrm{C}_{6}$ & 0.121 & 0.119 & 0.756 \\
\hline $\mathrm{C}_{7}$ & 0.000 & 0.233 & 0.750 \\
\hline $\mathrm{C}_{8}$ & $-0.033(0.957)$ & 0.164 & 0.826 \\
\hline $\mathrm{C}_{9}$ & $-0.033(0.957)$ & 0.164 & 0.063 \\
\hline
\end{tabular}

軸に垂直なので， b 軸はこの面内にあるが，a 朝は紙面 飞傾斜し，図上 $\alpha \sin \beta$ の関係汇縮小されている。

第11図に拉いて，I. PP. 鎖中 $\mathrm{CH}_{3}$ 基の高さの関係を 示した。气の数值は紙面からの高さ定表わし, $\mathrm{ab}$ 面か らの高さではない。このため，図中 1 の上の $\mathrm{CH}_{3}$ 基の 高さ 7/12 に対し, $1^{\prime}$ の同位の $\mathrm{CH}_{3}$ 基の高さは $5 / 12$ となっている。これは紙面と $\mathrm{a}$ 軸の傾斜の違い $|a \cos \beta|$ $=c / 6=c \cdot 2 / 12$ を示するので，ちょらど 1 周期ずれて いるので, 本当のるkは違いはない。

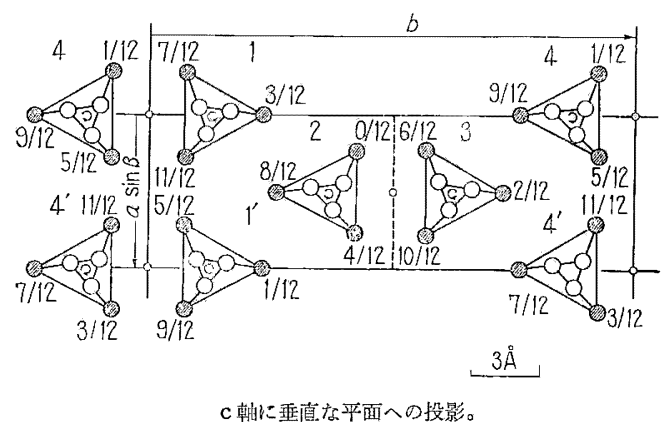

第 11 図 $\mathrm{C}_{b}$ 空間群としての I. PP. 単斜晶。

\section{5-2-2. $\mathrm{C}_{2 / 0}$ 空間群}

$C_{2 / c}$ 空間群を第 12 図纪示す7)。正摫の $C_{2 / c}$ 空間群は

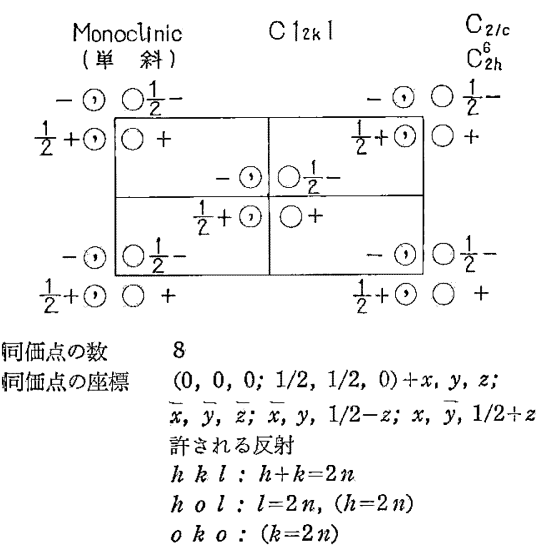

第 12 図 $\mathrm{C}_{2 / c}$ 空間群 
位置の数は八つであり，I．PP. 鎖4 本に対し，倍にな ってしまう。この場合には側鎖下向右巻と側鎖上向右巻 が，側鎖下向左巻と側鎖上向左巻が統計的に乐じりあっ $\tau$ ，平均的には unit cell 中江 I. PP. 鎖が 4 本存在す るといった棈造を考旮れ゙よい。

I. PP. 鎖の原子配置は, 第 2 表の值をとり, 第 12 図 代代入して全座標が得られる。これ炕よる，第 9 図化 導いた 4 種の I. PP. 骨格が全部現われる。

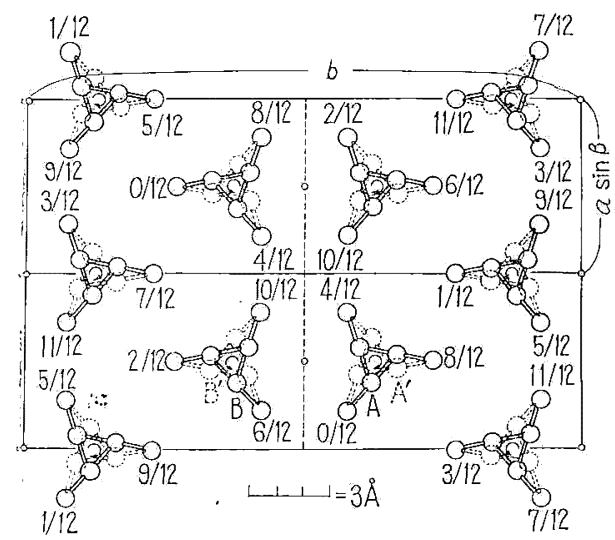

(001) 面への投影1)。

第 13 図 $\mathrm{C}_{2 / c}$ 空閒群としての I. PP. の結晶構造。

第 13 図に $C_{2 / c}$ 飞空間群による配置を示した ${ }^{1)}$ 。実線 部と点線部は $x, y, z$ 飞 $\vec{x}, y, \frac{1}{2}-z$ の関係飞西り，こ のいずれかが現われる。

\section{$5-3 . \quad$ 構造因子 1 )}

構造因子は，水素原子を無視し，炭素原子について第 2 図の $x, y, z$ を $C_{c}$ 空間群では,

$$
\left.\begin{array}{rl}
A=\sum & 4 f_{c} \cos ^{2} 2 \pi \frac{h+k}{4} \cos 2 \pi\left(h x+k y+l z+\frac{l}{4}\right) \\
& \times \cos 2 \pi\left(k y-\frac{l}{4}\right) \\
B=\sum & 4 f_{c} \cos ^{2} 2 \pi \frac{h+k}{4} \sin 2 \pi\left(h x+k y+l z+\frac{l}{4}\right) \\
& \times \cos 2 \pi\left(k y-\frac{l}{4}\right)
\end{array}\right\}
$$

$\mathbb{C}_{2 / c}$ 空閒群で性

$$
\begin{aligned}
A= & \sum 4 f_{c} \cos ^{2} 2 \pi \frac{h+k}{4} \cos 2 \pi\left(h x+l z+\frac{l}{4}\right) \\
& \times \cos 2 \pi\left(k y-\frac{l}{4}\right)
\end{aligned}
$$

記代入すればよい7)。 $C_{2 / c}$ 空間群は本来なら $A=\sum 8 f_{c} \cdots$ となるが，I. PP.の $C_{2 / c}$ 構造は統計構造で I. PP. 鎖 が 4 本しか入らないので $\sum 4 f_{0} \cdots \cdots$ となる。

構造因子は $C_{0}$ では $F=\left(A^{2}+B^{2}\right)^{\frac{1}{2}}, C_{2 / c}$ で忙 $F=A$ となるわけであるが，温度因子 $B$ を $C_{c}$ のとき $8.5 \AA^{2}$, $C_{2 / 0}$ のとき $7.5 \AA^{2}$ として $\exp \left\{-B(\sin \theta / \lambda)^{2}\right\}$ の形で上 述の下值使乘じた。 ( $h 00), F(0 k 0)$ 飞つては， $\sqrt{2}$ て割ったものを構造因
子とした。

Natta の計算した結界を第 3 表に示ず)。

第 3 表 ポリプロピレンの構造因子, 実測值 $F_{O}$ と計算值 $F_{C}$ の比較 $F_{O}$ は角度による補正を行な

\begin{tabular}{|c|c|c|c|c|c|c|c|}
\hline$h k l$ & $F_{O}$ & $\begin{array}{c}F_{C} \\
C_{2 / C}\end{array}$ & $\begin{array}{l}F_{C} \\
C_{O}\end{array}$ & $h k l$ & $F_{O}$ & $\begin{array}{l}F_{C} \\
C_{2 / C}\end{array}$ & $\begin{array}{l}F_{\sigma} \\
C_{O}\end{array}$ \\
\hline 020 & - & $<1$ & $<1$ & 2160 & - & 6 & \\
\hline $\begin{array}{lll}1 & 1 & 0\end{array}$ & 55 & 62 & 61 & 1170 & - & 5 & \\
\hline $0 \quad 40$ & 54 & 55 & 54 & $\left.\begin{array}{lll}5 & 7 & 0\end{array}\right\}$ & $y$ & 9 & \\
\hline 130 & 64 & 61 & 60 & $\begin{array}{lll}4 & 12 & 0\end{array}$ & & & \\
\hline $\left.\begin{array}{lll}1 & 5 & 0 \\
0 & 6 & 0\end{array}\right\}$ & 35 & 30 & 30 & $\left.\begin{array}{rrr}0 & 18 & 0 \\
5 & 9 & 0\end{array}\right\}$ & 7 & 5 & \\
\hline 200 & 18 & 19 & 19 & 4140 & - & 3 & \\
\hline 220 & 34 & 29 & 28 & $\begin{array}{lll}2 & 18 & 0\end{array}$ & & & \\
\hline 240 & - & 6 & 6 & $\left.\begin{array}{lll}6 & 0 & 0\end{array}\right\}$ & - & 7 & \\
\hline 170 & 12 & 11 & 13 & $\begin{array}{lll}1 & 19 & 0\end{array}$ & & & \\
\hline $0 \quad 80$ & 3 & 5 & 5 & 5110 & - & 3 & \\
\hline 260 & 0 & 14 & 14 & 3170 & - & $<1$ & \\
\hline $\left.\begin{array}{lll}1 & 9 & 0\end{array}\right\}$ & & & & $0 \quad 21$ & - & 1 & \\
\hline $\left.\begin{array}{lll}3 & 1 & 0\end{array}\right\}$ & 15 & 17 & 19 & $11 \overline{1}$ & 3 & 4 & 5 \\
\hline 0100 & - & 5 & 5 & 111 & 47 & 41 & 46 \\
\hline $\begin{array}{lll}3 & 3 & 0\end{array}$ & - & 7 & 9 & $13 \overline{1}_{\}}$ & 67 & 62 & \\
\hline 280 & 12 & 12 & 16 & $\left.\begin{array}{lll}0 & 4 & 1\end{array}\right\}$ & 67 & 62 & \\
\hline $\begin{array}{lll}3 & 5 & 0\end{array}$ & & 6 & 6 & $\begin{array}{lll}1 & 3 & 1\end{array}$ & 12 & 12 & 14 \\
\hline 1110 & - & 2 & 7 & $\begin{array}{lll}1 & 5 & 1\end{array}$ & 7 & 8 & 10 \\
\hline $\left.\begin{array}{lll}2 & 10 & 0\end{array}\right\}$ & 9 & 9 & 9 & $\begin{array}{lll}0 & 61\end{array}$ & - & 2 & 10 \\
\hline $\left.\begin{array}{lll}3 & 7 & 0\end{array}\right\}$ & 9 & 9 & 9 & $\left.\begin{array}{lll}2 & 2 & \overline{1}\end{array}\right\}$ & & 9 & \\
\hline 0120 & 10 & 9 & 9 & $\left.\begin{array}{lll}1 & 5 & 1\end{array}\right\}$ & 0 & 9 & 20 \\
\hline $\left.\begin{array}{lll}4 & 0 & 0 \\
4 & 2 & 0\end{array}\right\}$ & 4 & 6 & 11 & $\left.\begin{array}{lll}2 & 4 & \overline{1} \\
2 & 2 & 1\end{array}\right\}$ & 16 & 8 & 36 \\
\hline $\begin{array}{lll}4 & 2 & 0) \\
3 & 9 & 0\end{array}$ & & & & $\begin{array}{ll}2 & 2 \\
1 & 7\end{array}$ & & & \\
\hline $\left.\begin{array}{rrr}3 & 9 & 0 \\
1 & 13 & 0\end{array}\right\}$ & & & & $\begin{array}{ll}1 & 7 \\
1\end{array}$ & 14 & 7 & 30 \\
\hline $\left.\begin{array}{lll}1 & 13 & 0 \\
& & \end{array}\right\}$ & 12 & 13 & 15 & $\begin{array}{lll}1 & 71\end{array}$ & - & 4 & 5 \\
\hline $\begin{array}{lll}4 & 4 & 0 \\
2 & 12 & 0\end{array}$ & & & & $\left.\begin{array}{lll}0 & 8 & 1\end{array}\right\}$ & 18 & 21 & \\
\hline 2120 & - & 3 & 11 & $\left.\begin{array}{lll}2 & 4 & 1\end{array}\right\}$ & & & \\
\hline $\left.\begin{array}{lll}0 & 14 & 0 \\
1\end{array}\right\}$ & 7 & 4 & 3 & $2 \quad 6 \overrightarrow{1}$ & 20 & 18 & 22 \\
\hline $\begin{array}{ccc}4 & 6 & 0 \\
3 & 11 & 0\end{array}$ & & & & $\left.\begin{array}{lll}3 & 1 & \overline{1}\end{array}\right\}$ & 13 & 1 & 12 \\
\hline 3110 & - & 3 & 8 & $\left.\begin{array}{lll}2 & 6 & 1\end{array}\right\}$ & & & \\
\hline $\begin{array}{lll}4 & 8 & 0\end{array}$ & 7 & 8 & 7 & $\begin{array}{lll}1 & 9 & I_{1}\end{array}$ & 21 & 22 & 23 \\
\hline $\left.\begin{array}{lll}1 & 15 & 0 \\
2 & 14 & 0\end{array}\right\}$ & 16 & 16 & 14 & $\left.\begin{array}{lll}3 & 3 & 1\end{array}\right\}$ & & & \\
\hline $\begin{array}{lll}2 & 14 & 0 \\
0 & 16 & 0\end{array}$ & & & & $\begin{array}{lll}1 & 9 & 1\end{array}$ & - & 2 & 2 \\
\hline $\left.\begin{array}{rrr}0 & 16 & 0 \\
5 & 1 & 0\end{array}\right\}$ & 12 & 9 & 10 & $\left.\begin{array}{rrr}2 & 8 & \overline{1} \\
0 & 10 & 1\end{array}\right\}$ & 17 & 20 & 29 \\
\hline $\left.\begin{array}{lll}3 & 13 & 0\end{array}\right)$ & & & & $\left(\begin{array}{lll}3 & 1 & 1\end{array}\right)$ & & & \\
\hline $\left.\begin{array}{rrr}4 & 10 & 0 \\
5 & 3 & 0\end{array}\right\}$ & 13 & 13 & 14 & $\left.\begin{array}{lll}3 & 5 & \overline{1} \\
3 & 3 & 1\end{array}\right\}$ & 15 & 24 & 28 \\
\hline$5 \longdiv { 5 0 } 0$ & 17 & 12 & 11 & 281 & - & 7 & 7 \\
\hline
\end{tabular}
った後のX線回折強度の平方根。温度因子の補正 ほ， $C_{2 / C}$ として計算の㭙, $B=7.5 \AA^{2}, C_{\sigma}$ の封怯 $B=8.5 \AA$ を用いた。多重度は $F(h o l), F(h o o)$, $F(o k o)$ のとき，檏造因子を $\sqrt{2}$ で割ったため, 挡りこんである1 
第 3 寈 (続)

\begin{tabular}{|c|c|c|c|c|c|c|c|}
\hline$h k l$ & $F_{0}$ & $\begin{array}{c}F_{G} \\
C_{2 / C}\end{array}$ & $\begin{array}{l}F_{C} \\
C_{C}\end{array}$ & $h l k l$ & $F_{0}$ & $\begin{array}{c}F_{O} \\
C_{2 / O}\end{array}$ & $\begin{array}{l}F_{G} \\
C_{C}\end{array}$ \\
\hline $\left.\begin{array}{rrr}3 & 5 & 1 \\
1 & 11 & 1\end{array}\right\}$ & 9 & 8 & 19 & $\begin{array}{ccc}4 & 4 & \mathbf{1} \\
1 & 13 & \mathbf{1}\end{array}$ & - & 6 & 8 \\
\hline $\begin{array}{lll}3 & 7 & 1\end{array}$ & - & $<1$ & 13 & $\left.\begin{array}{lll}2 & 12 & 1\end{array}\right\}$ & 16 & 13 & 16 \\
\hline $\left.\begin{array}{lll}1 & 11 & 1 \\
2 & 10 & 1\end{array}\right\}$ & 10 & 13 & 16 & $\left.\begin{array}{ccc}4 & 2 & 1\end{array}\right)$ & - & 5 & 6 \\
\hline $\begin{array}{ll}0 & 121\end{array}$ & - & 8 & 8 & $\begin{array}{lll}3 & 9 & 1\end{array}$ & - & 9 & 8 \\
\hline $\left.2 \begin{array}{lll}2 & 10 & 1\end{array}\right)$ & & & & $46 \mathbf{1}$ & - & 3 & 3 \\
\hline $\left.\begin{array}{lll}3 & 7 & 1\end{array}\right\}$ & 11 & 14 & 15 & 2121 & - & 5 & 6 \\
\hline $\left.\begin{array}{lll}4 & 2 & 1\end{array}\right)$ & & & & $4 \quad 41$ & - & 1 & 2 \\
\hline $39 \overline{1}$ & - & 5 & 6 & & & & \\
\hline
\end{tabular}

第 3 表から，一般的に $C_{2} / \mathrm{c}$ 空間群から求めた $|\boldsymbol{F}|$ は, $C_{c}$ 空間群から求めたるのより小さな值をとる。これは $C_{0}$ の方が規則的楧造で， $C_{2 / c}$ の方が統計的に disorder を示す楧造なことを示す。しかし両者の違いは余りな く，いずれの方が正しいといら判断はできない。

Natta はさらに電子密度分布の計算を行ない，第 14 図, 第 2 表にかかげた原子座標の正しいことを実証した。

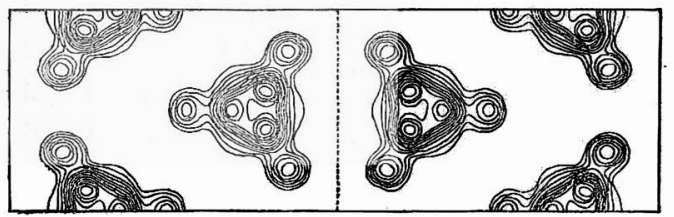

等高線は $2 \mathrm{e} / \AA^{2}$ から $0.5 \mathrm{e} / \AA^{2}$ ごとにかいた。 第 14 図 $C_{2} / 0$ 空間群として計算した I.PP.の (001) 面への電子密度投影図。

このように, I. PP. 単斜晶については空間群が $C_{0}$ で あるか $C_{2 / 0}$ であるかの不確定性を除くと，㴗とんど完 全な結晶解析が, Natta の手によってなされている。

\section{I. PP. の 変 態}

I. PP. の変態について多くの人が提唱しているが, その代表的なものは, Padden, Keith らの球晶による 分類 ${ }^{3), 8)}$, Addink, Beintema に上る結晶構造的分類9) である。

\section{6-1. 球晶による变態}

Padden, Keith らはI. PP. の球晶成長を調べて, 次 の五つの変態を分類した ${ }^{3), 8) 。 ~}$

I 型…単斜晶。 $134^{\circ} \mathrm{C}$ 以下で発生。複屈折 +0.003 $\pm 0.001$

II型…単斜晶。 $138^{\circ} \mathrm{C}$ 以上で発生。複屈折 -0.002 $\pm 0.0005$

Mix型・単斜晶。 $138^{\circ} \mathrm{C}$ 付近でみられ，+, 一の複屈 折の混合晶。

III型…六方晶。 $128^{\circ} \mathrm{C}$ 以下で I 型中にまじって発
生。複風折 $-0.007 \pm 0.001$

$\mathrm{IV}$ 型…六方晶。血型似似て, 鱗片状模様。

結晶構造的には I， II，Mix 型の区別はつかない。 IIIIVI型も同様である。これらの偏光顕微鏡写真を写真 3,4 に揭げる。

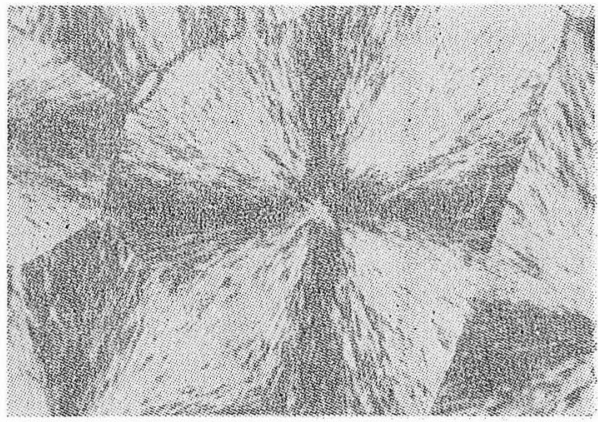

（1） I 型球晶(Padden, Keith)

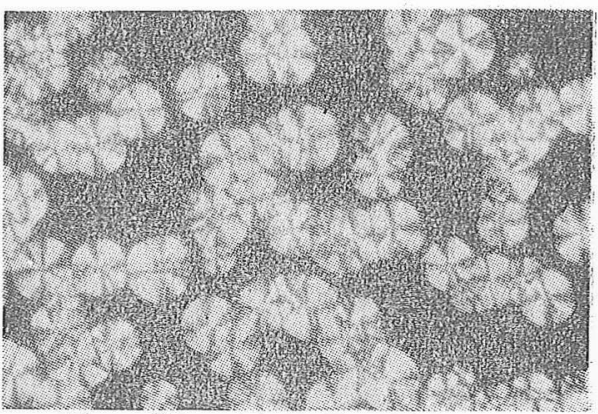

(2) II 型球晶

写真 3. 単斜晶変態（偏光顕微鏡クロスニコル)

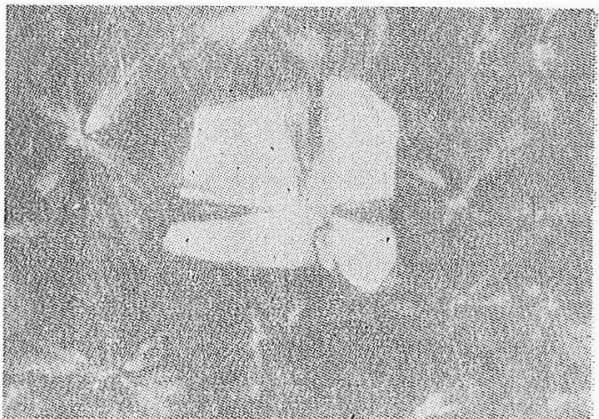

(1) III型球晶(Padden, Keith)

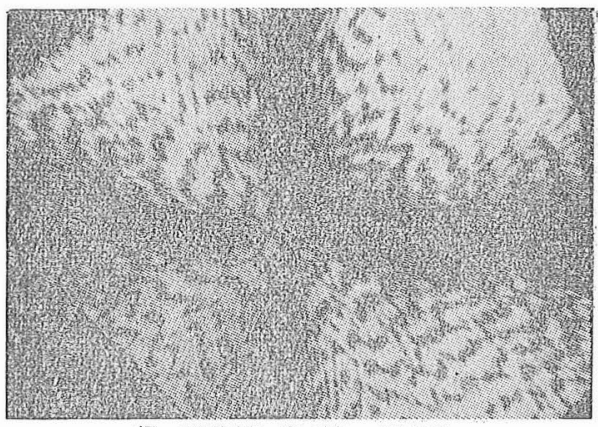

(2) IV型球晶 (Padden, Keith)

写真 4 六方晶球晶（偏光顕微鏡クロスニコル） 


\section{6-2. 結晶構造による分類}

Addink, Beintema らは Schooten らの分别した I. PP. 試料のX線回折を行ない, 四つの変態を見出し た9)。

\section{6-2-1. $\quad \alpha$ 変態}

Keith の I, II型球晶がこれに相当し, 今京でに述べ た単斜晶である。

\section{6-2-2. $\beta$ 変態}

Isotacticity のよいものにみられる。いわゆる六方晶 変態である。(第4 表)

Keith らは $a=12.74 \AA, c \approx 6.35 \AA$ の六方晶で, 右, 左ラセンの I. PP. 鎖が 交互に並んだ期造を考えだ (第15図)。

第 4. I. PP. $\beta$ 変態のX線回折

\begin{tabular}{|c|c|c|c|c|}
\hline \multirow{2}{*}{$\left(\begin{array}{c}2 \stackrel{\theta}{\mathrm{Cu}}-\mathrm{K}_{\alpha} \\
)\end{array}\right.$} & \multirow{2}{*}{$\left(\begin{array}{l}\mathrm{d} \\
(\stackrel{\mathrm{A}}{\mathrm{A}})\end{array}\right.$} & \multirow{2}{*}{ 強 度 } & \multicolumn{2}{|c|}{$h \quad k \quad l$} \\
\hline & & & Addink 5 & Keith 5 \\
\hline $16.3^{\circ}$ & 5.5 & S & 100 & 200 \\
\hline $21.2^{\circ}$ & 4.2 & $m$ & 101 & 201 \\
\hline
\end{tabular}

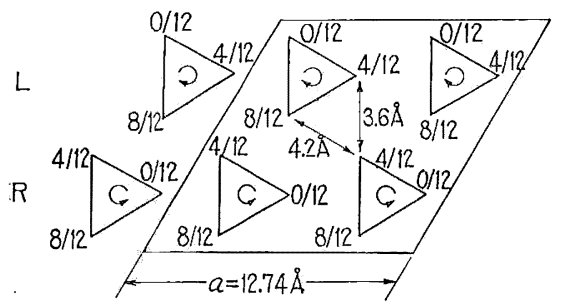

第 15 図 Keith の六方充てん（メチル基の位置の 为示守。)
しかし Addink らは第15図の場合，六方充てんでな く斜方晶にしかなりえず，なだ図中…線で示したとこ ろの隣接メチル基間距離が $3.6 \AA$ となり，1個のメチル 基の van der Waals 半径 $2 \AA$ から考允られる最短距離 $4 \AA$ 尗小さいため，このような充てんが事実上不可能 なことを示した。

Addink らは $\beta$ 変態の unit cell は全部右ラセンのみ, あるいは左ラセンのみの I. PP. 鎖から成り，から単斜 の $C_{2} / c$ の場合同㥞，侧鎖上向きと下向きが統計的にま じりあった柾造であるとした。

三方晶系，空間群は $\mathrm{P}_{1} 21-\mathrm{D}_{3}^{4}$ あるいは $\mathrm{P} 3_{2} 21$ 一 $\mathrm{D}_{3}{ }^{6}$ で $a=6.38 \AA, C=6.33 \AA$, 同一方向のラセン回転の I. PP. 鎖が各頂点に存在する。彼女らの諭欢に Anaclinic, Cataclinic とあるのは，それぞれ側鎖上向，側鎖 下问の意である(筑 16 図)。

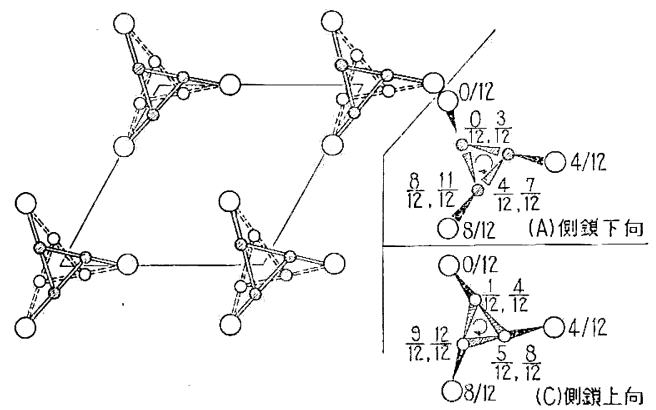

第 16 図 I. PP. $\beta$-変態の絬晶構造の (100) 面への 投影。(侧鎖下向 $(\mathrm{A})$ と上向 (C) の鎖が まざりあっている。)

Addink らの考えに基いて原子座標を求めると第 5 表 のごとくである。

第 5 表 I. PP. 六方晶の原子座標

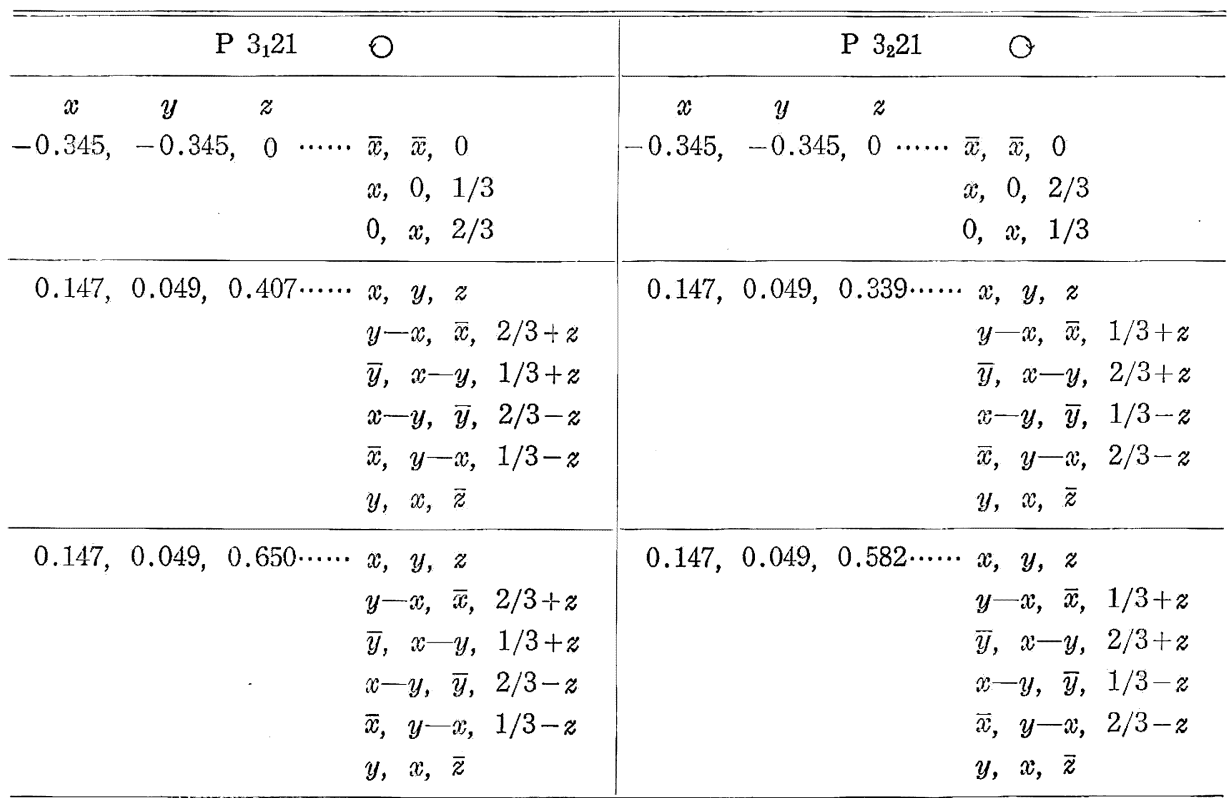


基本になる原子は 3 種である。

この結晶解析はわずか 2 本の回折線から得たものにす ぎない。しかし, 最近, 静岡大藤原らが配向結晶化法に よって, 純粋の $\beta$ 変態試料を得ているので10), 完全な結 晶解析がなされるのも時間の問題である。

簕者の実験以よると，六方晶変態は右，左ラセンの I. PP. 鎖が交互に出る構造の方が考方やすい(11),12)。こ の点についてはさらに倹討をしたいと思う。

\section{6-2-3. $\gamma$-变 態}

低分子量の試料にのみ見られる。Polymer chain の高 度の動きやすさが，この変態のできる条件である。かな りの反射線が微湘されながら，指数配当をなされていな い(第6 表)。

第 6 表 I. PP. $\gamma$-変態の X線回折 ${ }^{9)}$

\begin{tabular}{c|c|c}
\hline \hline $\begin{array}{c}2 \theta \\
(\mathrm{Cu}-\mathrm{K} \alpha)\end{array}$ & $\begin{array}{c}\mathrm{d} \\
(\AA)\end{array}$ & 強 度 \\
\hline $13.8^{\circ}$ & 6.4 & $\mathrm{~m}$ \\
$15.3^{\circ}$ & 5.8 & $\mathrm{mw}$ \\
$20.2^{\circ}$ & 4.4 & $\mathrm{vs}$ \\
$28.1^{\circ}$ & 3.18 & $\mathrm{w}$ \\
$32.0^{\circ}$ & 2.80 & $\mathrm{mw}$ \\
$35.3^{\circ}$ & 2.54 & $\mathrm{~m}$ \\
$36.5^{\circ}$ & 2.46 & $\mathrm{w}$ \\
$40.6^{\circ}$ & 2.22 & $\mathrm{w}$ \\
$42.6^{\circ}$ & 2.12 & $\mathrm{mw}$ \\
\hline
\end{tabular}

\section{6-2-4. $\quad 8$-変 態}

抽出によってアイソタクチックな物質のバルクから分 離された Amorphous 物質を多量に含んだ試料中にの み観测される。

シンジオタクチック・PP， と類似しているので，I. PP. の $\delta$ 変態とみるか, シンジオタクチック $=\mathrm{PP}$.な のか区別しにくい。最近は同一なものと考克られる（第 7 表)。

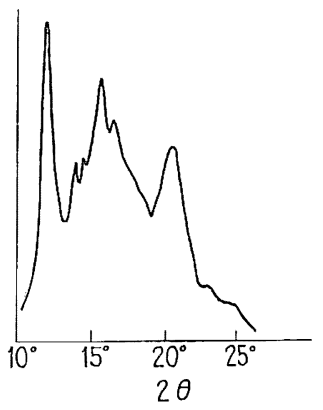

第 17 図 シンジオタクチックポリプロピレン の $\mathrm{X}$ 線ガイガースペクトル $(\mathrm{Cu}-\mathrm{K} \alpha$ 線使用 $)^{13)}$

\section{6-3. 擬六方変態}

6-1,2 に括ちた I. PP. の変態として擬六方（スメッ チック）変態がある。これは Natta の考え方によると, $a \approx 6.5 \AA, c \approx 6.5 \AA$ の六方晶 unit cell 中に右, 左ラ゙ センのI. PP. 鎖が案じり亦って第 18 図のように配列し たものである14)。

このスメクチック変態は， $70^{\circ} \mathrm{C}$ 以下で泠延伸したとき や，溶融した I. PP. を急冷したときにみられる。比重 は 0.88 ぐらいである。

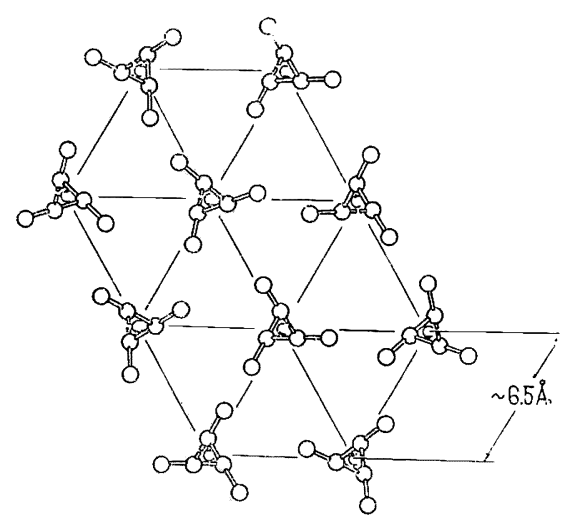

第 18 図擬六方 I. PP. の搆造 14 ?

第 7 表 I. PP. の $\delta$ 変態とシンジオタクチック・PP.のX線回折

\begin{tabular}{|c|c|c|c|c|c|c|c|c|}
\hline \multicolumn{4}{|c|}{$\delta$ 変態9) } & \multicolumn{5}{|c|}{ Syndiotactic $\cdot P P$. } \\
\hline $\begin{array}{c}2 \theta \\
(\mathrm{Cu}-\mathrm{K} \alpha)\end{array}$ & $\begin{array}{c}d \\
(\stackrel{\AA}{\AA})\end{array}$ & Int. & $h k l$ & $\begin{array}{c}2 \theta \\
(\mathrm{Cu}-\mathrm{K} \alpha)\end{array}$ & $\begin{array}{c}\mathrm{d} \\
(\AA)\end{array}$ & $\begin{array}{l}\text { Int.* } \\
\text { obs. }\end{array}$ & $\begin{array}{l}\text { Int.*** } \\
\text { cal. }\end{array}$ & $h k l$ \\
\hline $12.5^{\circ}$ & 7.1 & $\mathrm{~s}$ & 200 & $12.2^{\circ}$ & 7.25 & vs & $\mathrm{s}$ & 200 \\
\hline $16.1^{\circ}$ & 5.5 & $\mathrm{~m}$ & 110 & $16.4^{\circ}$ & 5.39 & $\mathrm{~s}$ & $\mathrm{~m}$ & 110 \\
\hline \multirow[t]{2}{*}{$16.9^{\circ}$} & 5.25 & $\mathrm{~s}$ & 201 & $17.1^{\circ}$ & 5.18 & $\mathrm{w}$ & s & 201 \\
\hline & & & & $20.4^{\circ}$ & 4.36 & vs & $\mathrm{s}$ & 111. \\
\hline \multirow[t]{2}{*}{$25.0^{\circ}$} & 3.56 & $\mathrm{w}$ & 400 & $24.5^{\circ}$ & 3.63 & $\mathrm{w}$ & $\mathrm{w}$ & 400 \\
\hline & & & & $30.6^{\circ}$ & 2.92 & - & vw & 020 \\
\hline
\end{tabular}




\section{I. PP. 単結晶}

\section{7-1. Rånby の単結晶 ${ }^{15}$}

I. PP.の単結晶をつくるのはきわめて困難である。こ れに成功したと最初に発裴したのが Rånby である。nヘキサン，n-ヘプタン拉よび $n$ ーベンゼンで抽出したき わめて純度の高いI. PP. を用いて， $p$-キシレンに溶解, $60^{\circ} \mathrm{C}$ の温度で単結晶をつくった (写真 5 )。

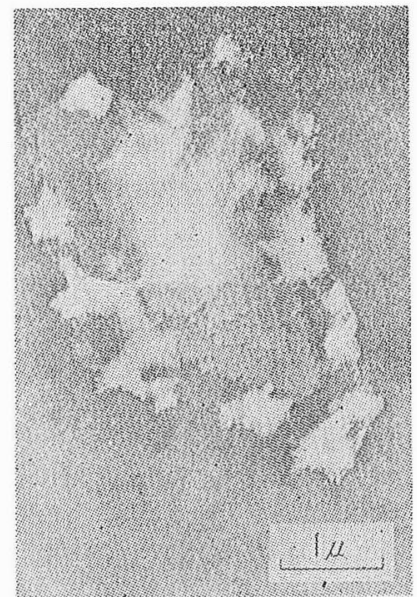

写真 5 Rånby の単結晶 ${ }^{15)}$ (電子顕微鏡)

I. PP. 鎖は右巻，左巻の 2 種のラセンをむら，斜万晶 のポリエチレンより対称性の悪いためか，ポリエチレン のような整った単結晶は得られにくい。

\section{7-2. Kargin らの単結晶 ${ }^{16}$}

ソビェトの Kargin らは I.PP.を0.01 0.05\%の キシレン溶液にし, 沸騰させてから䈭法びん中で $2 \sim 3$ 週間かけて室温まで徐冷し，単結晶を得たという。

\section{7-3. Geil の単結晶 $\left.{ }^{17}\right)$}

Geil はI.PP. を溶融状態から結晶化してつくった film から単結晶, あるいは Spiralgrowth の結唱を得た。写 真 6 は去の 1 例である。

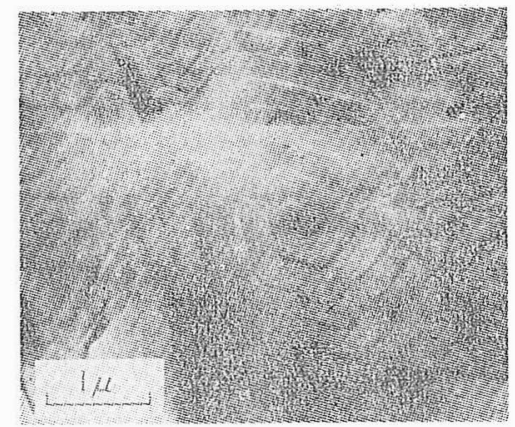

写真 6 ポリプロピレンを溶融結晶化してつくっ たフィルム中にみられたラセン成長 (Geil) ${ }^{17)}$

こらして得た単結晶の電子線回折は六角形模㥞を呈し ている。 .

7-4. 小林の単結晶 55

Vol. 14, No. 158
I.PP.を溶液から析出させると，写真 7 のよらなデン ドライトを生じる。これの電子線回折をとると，写真 2 のごとくでこのデンドライトは単結晶的鈢造なことが わかった。

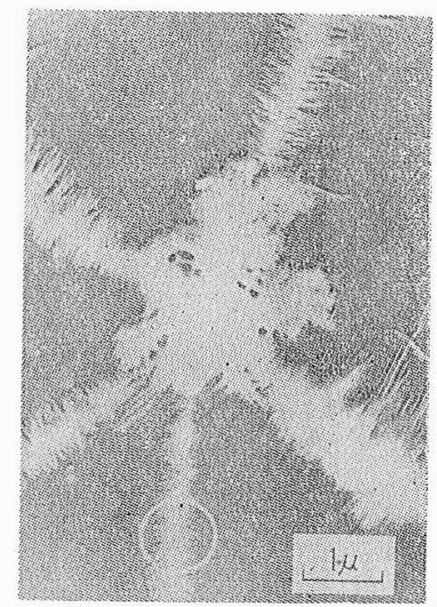

写真 7 小林の単結晶 ${ }^{5}$ ( $(○ の$ 所の電子線回折は 単結晶棈造を示した）

\section{Folding について}

ポリエチレンの結晶は第 19 図のような folding を示 している。では I.PP. の結晶についてはいか炕考えた らよいか。

もし第 20 図のよらに folding してゆくものと考光た らどうであるらか。今 $C_{c}$ 空間群で図中の 1 を側鎖上向 右巻とすると， 2 は側鎖上向左巻である。しかし，1の 側鎖上向右巻が fold して方向をか竞ると, 側鎖下向右 巻となるはずで， 2 の側鎖上向左巻と食違う。だが 1 の 側鎖上向右巻は C-C-C ジグザグ面に対し側鎖が上に でているもので, 2 の側鎖上向左巻, 1 の裏返し側鎖下 向右巻はともに, ジグザグ面に対し側鎖が下にでている ものである。艺こで fold に上る方向換克は，C-C-C 面に対し側鎖が上側か下側かといらことが問題になり, fold してから，ラセンの巻き方が右巻きが左巻きにな るなど，逆になっても，それは本質的に差はないのだと 考学ると，第 20 図に抹いて，Co 空間群をとっても 12-1'といったつながりをしても矛盾はない。 $C_{2 / 0}$ 空間 群の場合でも, fold した後, ラセンの巻き方が逆にな らなくてはならない。

六方晶について Addink の考觉をとった場合, 一つ の unit cell 内では, 皆ラセンの巻き方は同じなので, fold してからの鎖のつながり方は, ずっと自由度をむ っている。

I.PP. の単斜晶単結晶がデンドライトのようなものし か得られず, Geil が六方晶でかなりタごとな単結晶を得 たのは,この fold した後, ラセンの向きが逆にならなけ ればならないか，そのままですむかといった性質に基く 
のであろらか。しかし，I．PP．の folding の方法は全 く打くそくの段階で，ポリェチレンの場合のようなみご とな見解が全く得られていないのは残念である。

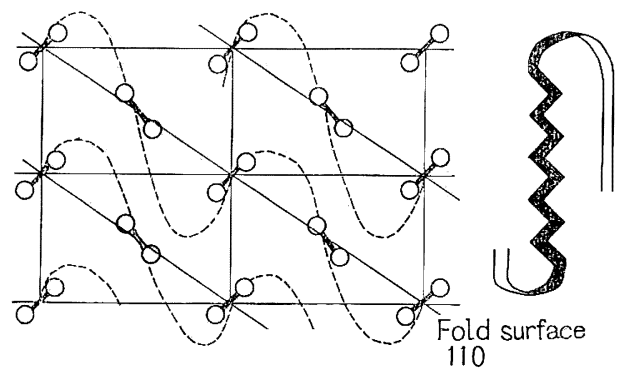

第 19 図 ポリエチレン鎖の折り返しかた(Folding)。 1つの面 (Fold 面) 汇沿って折り返しが くりかえされる。
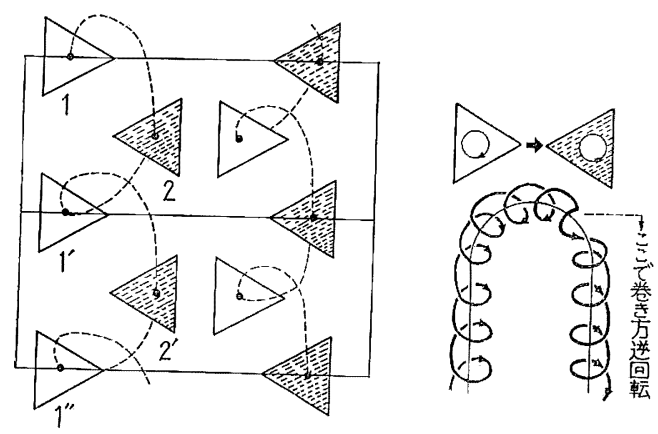

第 20 图 I. PP. 鎖の折り返しかた（Folding）の 可能性。

\section{9. 結 言}

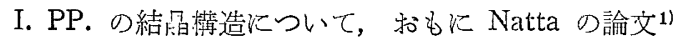
を中心にをとめてみた。I.PP.の赤外吸収などの解説は すでに田所氏なぞの手によって本誌屾りらている が，X線回折的な結晶構造はかなり不十分なるのしかの
せられていない。これは冒頭に述べたように，Natta の 発表した論文があまりにる特殊な本であったために他な らない。そこで，この論文を骨にして，結晶構造の問題 に終始した次第である。そして，それに関連した結晶化 度の問題にも当然ふれるべきであるが，紙数がかなりの ものになったので，これで筹をとどめる。

$$
\text { 文献 }
$$

1) G. Natta, P. Corrdini: N 1 del Supplementoal 15, Serie X, del Nuovo Ciment, 40 (1960)

2) G. Natta: Angew. Chem., 68, 393 (1956)

3) H. D. Keith, F. J. Padden, N. M. Walter, H. W. Wyckoff: J. Appl. Phys., 30, 1485 (1959)

4) 栗屋 裕：日化，82，1575 (1961)

5）小林恵之助：“高分子の物性”，218 (1962) 化学同 人

6）田所宏行，茶谷陽三：“高分子の構造と物性” 61 (1963) (丸善)

7) International Tables for $\mathrm{X}$-ray Crystallography, 1, Symmetry Groups, (1959) (Kynoch Press)

8) F.J. Padden, H.D. Keith: J. Appl. Phys., 30, 1479 (1959)

9) E. J. Addink, J. Beintema: Polymer, 2, 185 (1961)

10）藤原靖名, 吉田稳穗：高分子学会第 12 回年次大会 (東京), 1963 年 5 月 25 日，

11) 粱屋 裕：日化, 83, 865 (1962)

12) 栵屋 裕: 高化, 20, 1 (1963)

13) G. Natta: J. American Chem. Soc., 84, 1488 (1962)

14) G. Natta: Makromol. Chemi., 35, 93 (1960)

15) B. G. Rånby et al: J. Polymer Sci., 44, 349 (1960)

16) V.A. Kargin et al: Visolo Moleculanie Soyedineniya, 2, \# 8, 1278 (1960)

17) P. H. Geil: J. Appl. Phys., 33, 642 (1962)

\section{会費・購読費の納入について}

39 年12月 31 日で下記の方々が会賽切れとなります。 至急ご納入下さい。

a. 該当者

i) 昭和 39 年度上期上り 1 力年間（昭和 39 年 1 月

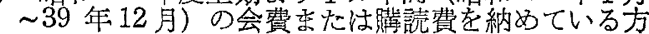

ii）昭和 39 年下期の2（昭和 39 年 7 12 月）の会費 または購読費を納めている方

iii）ただし，正会貫の場合，会費改正により，39年下 期分 (7 12 月) 老旧会費 $(6000)$ で納めている方に かぎり，不足分として 200 円 納めていただきすす。

b. 送金方法

i) 送金誌とじ込みの振替用紙を使用されるのが最る便 利です。その他現金, 小切手, ・為替などの場合は 必ず書留で特送り下さい(書留以外の場合, 事故発 生があっても責任は負いません)。

ii) 振替用紙の通信橛には，氏名・会員番号・送金の 明細を必ずこ記入下さい。 iii）送付先は高分子学会会員課（東京都中央区日 本橋本町 3-9 䋐維会館 2 階)

電話による和問合せは㨁接会貝課へねがいます。 菓京 (253) 8703 - (251) 5545

c. 金 額

（円）

\begin{tabular}{|c|c|c|}
\hline & $\left.\begin{array}{c}1 \text { 力年 } \\
(\text { 昭和 } \\
40 \text { 年上年下期 }\end{array}\right)$ & $\begin{array}{c}\text { 半力年 } \\
\text { (昭和40年上期) }\end{array}$ \\
\hline 正会員会費 & $\begin{array}{l}800 \text { (上期) } \\
800 \text { (下期) }\end{array}$ & 800 \\
\hline 会費改正に上る不足分 & 39年下期 200 & 39年下期 200 \\
\hline \multirow{2}{*}{$\begin{array}{l}\text { 「高分子化学」矔読費 } \\
\text { 「海外高分子研究」瞒読費 }\end{array}$} & 1,320 & 660 \\
\hline & 1.800 & 900 \\
\hline
\end{tabular}

